\title{
اتجاهات أطباء مدينة دمشق نحو مسائل الخدمة النفسية
}

The attitudes of Damascus city Physicians toward psychological service issues

$$
\text { د. دامر جميل رضوان }
$$

\section{Samer Rudwan}

https://orcid.org/0000-0002-8844-1307

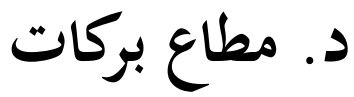 \\ Mouta Barakat}

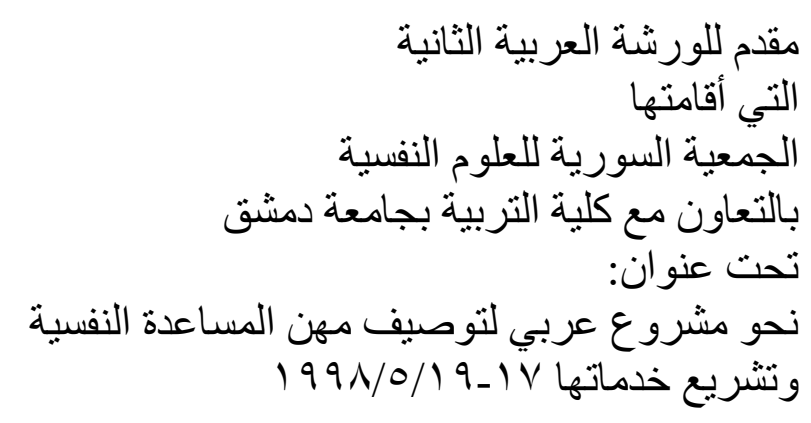




\section{أولاً: الإطار النظري}

\section{ا ـ تظور مفهوم المرض في النصف الثاني من القرن العشرين:}

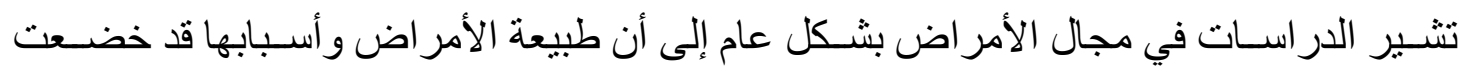

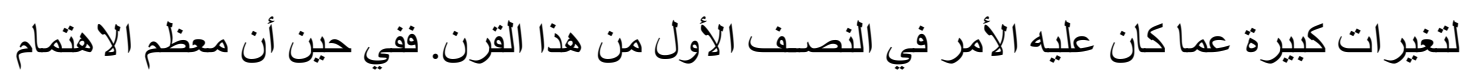
كان منصـباً على الأمر اض المعدية فقد أصـبحت الأمر اض المزمنة هي الأكثر ملاحظة في وقتنا

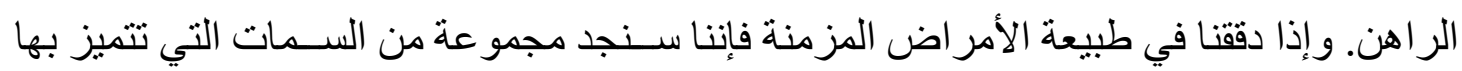
هذه الأمر اض يمكن إجمالها بالنقاط التالية (Schultz \& Hehlhammer, 1994) : - الأسباب: في حين أن الأمر اض المعدية تثار من خلال الفيروسات و الجر اثيم فإن هناك علاقة وطيدة بين غالبية الأمر اض المزمنة وبين نمط الحياة و السلوك و العو امل الاجتماعية والنفسية.

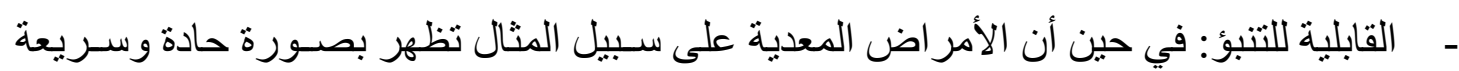

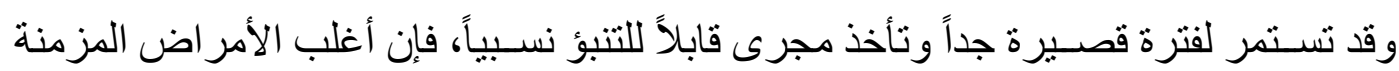

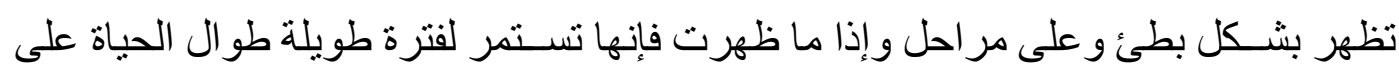
الأغلب مع الإشارة إلى أن مجر اها غير قابل للتنبؤ في أغلب الحالات.

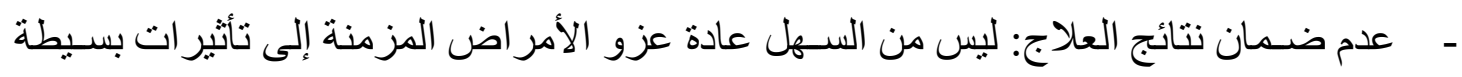

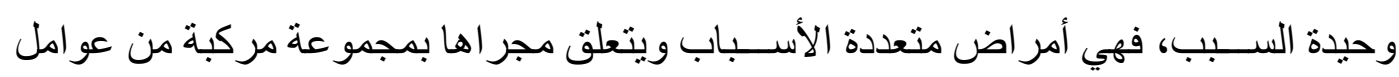

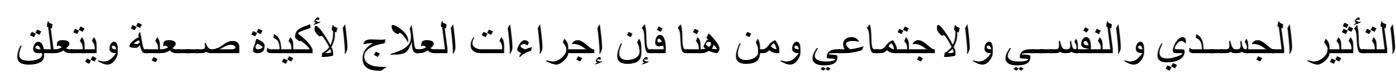
النجاح بمدى فاعلية المريض في الإسهام في العلاج.

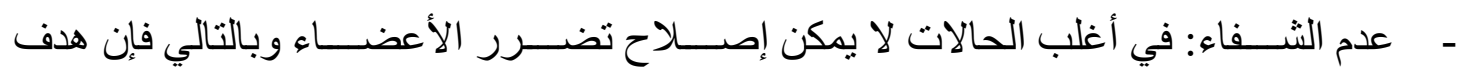

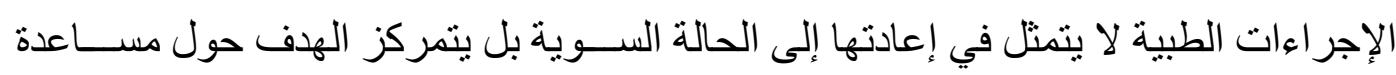
المريض كي يتعايش مع مرضد. - التكاليف: إن معالجة الأمر اض المزمنة مكلفة جداً لما تتطلبه من أجهزة وكو ادر مؤهلة تأهيلاً جيداً مما يستتبع ازدياد التكاليف المباثرة وغير المبر المباشرة.

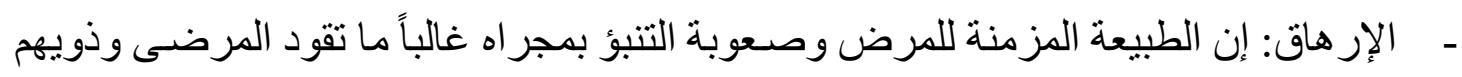

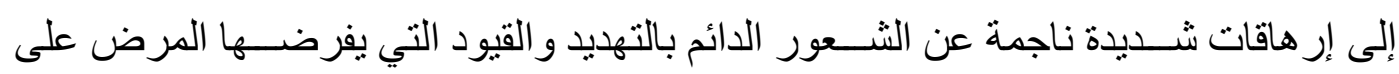

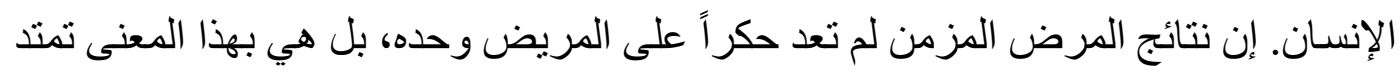

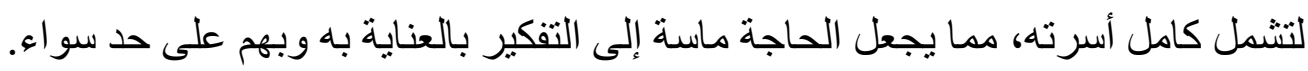


وكل هذه السمات و العو امل جعلت الطب و المؤسسات الصحية في العالم ذات الاتجاهات العضوية الخالصــــة والتي تتبنى مفاهيم تقليدية للمرض عاجزة وحدها عن مواجهة الأمر اض المزمنة مما دفع إلى إعادة النظر في مفهومها للمرض ليثـــتمل على الوجوه النفسـيـة والاجتمـاعية للمرض وبالتالي إشر الك التخصصات و التعاون معها وبشكل خاص علم النفس لأن المظاهر المتنوعة التي لابد من مر اعاتها كبيرة جداً و إعادة التأهيل للأمر اض المزمنـة متفرعة ومتشــعبة و الإرهاقات النفسية والاجتماعية الناجمة كبيرة الأمر الذي لا يمكن لتخصـص واحد أن بغطيه وحده. كما وأن احتكالك الأطباء اليومي مع الأمر اض المزمنة وإدر اكهم المتز ايد لضرورة مر اعاة العوامل النفسية في الأمر اض الجســدية وغير ها و عدم توفر المعارف النفسـية اللازمة لدى الأطباء نمَّت الحاجة إلى المعارف النفسية و إلى إثر الك المتخصصين النفسيين في الإشر اف و العلاج و إعادة التأهيل. وقد تر افقت هذه التغير ات في العالم مع التبدل الحاصـل في الوعي سـواء من جهة الجمهور أم في جهة المتخصصين أنفسهم (Grawe, Donati \& Bernauer,1994) الأمر الذي أدى إلى خروج الطب عن مفاهيمه التقليدية للمرض و اعتبار مسألة الأمر اض عموماً مسألة اجتماعية ونفسية تمس الجوانب

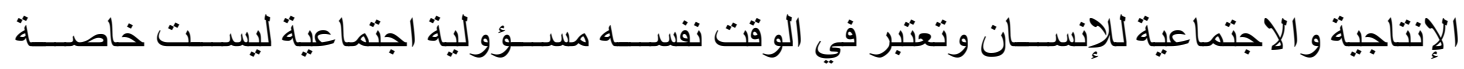
بالتخصـصـات الطبية وحدها بل عامة تشـمل جميع التخصـصـات التي لها علاقة مباشـرة أو غير مباثـــرة بالإنســان. وقد أثمرت الجهود العلمية والحقائق الواقعية في الدول المتقدمة عن تبلور صـور متنو عة من أثــكال التعاون بين الأطباء و الأطباء النفسـبين و المتخصــــين النفسـبين و المتخصـصــين الاجتماعيين و علماء البيئة. وقاد هذا التعاون بدوره إلى وضــوح لدور كثير من التأثير ات النفسية و الاجتماعية والفيزيولوجية وتفاعلها مع بعضـها على نشوء وتطور المرض أو على الحفاظ على الصحة وتنميتها (Hurellman \& Lasser, 1993) .

\section{الفريق أو الطاقم العلاجي: نموذج للتعاون المجدي}

يذكر شــيت (نقلاً عن Janosik 1989 أن هنالك ثلاث نماذج ســائدة لإمكانات العمل ضــمن فريق علاجي متكامل. النموذج الأول هو الفريق ذو التخصــص الواحد Unidisciplinary Team، حيث يجتمع عدد من الأثشخاص المتخصصسين في المجال نفسـه للتعاون على رعاية حالات ثقع ضــن supervision نطاق اختصاصهم، منتل اجتماع عدد من المعالجين النفسيين لتبادل الخبر ات و المشورة حول الحالات التي يتتاولونها، و الغالب أن لهذه الفرق طبيعة تعليمية تدريبية. أما النموذج الثاني فهو الفريق متعدد التخصـصـات Multidisciplinary Team، و هو يتألف من مجمو عة من الأشـخاص الذين يختصـــون في مجالات مختلفة، ويهتمون في نفس الوقت بظـاهرة أو بحالة محددة تمت 
اختصاصاتهم إليها بشيء من الصلة، كاجتماع الطبيب النفسي مع طبيب الأسرة و المعالج النفسي، بالإضـافة إلى المتخصـص الاجتماعي أو المتخصسص في التربية الخاصـة و إعادة التأهيل لتغطية جو انب مختلفة تتعلق بطبيعة الإشـــر اف و الر عاية اللازمة للحالة موضـــوع البحث. أما النموذج

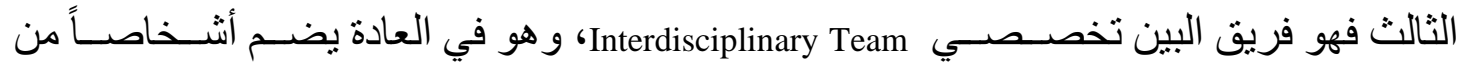
تخصصات قريبة من بعضها أو هي تخصصات فر عية لاتجاه تخصصي أشمل، كاجتماع الطبيب النفسـي مع طبيب الأعصــاب وطبيب التغذية، أو اجتماع المعالج النفسـي مع المرشــــ النفسـي و اختصاصي القياس النفسي. و عندما يذكر الفريق العلاجي في الأدبيات النفسـية، فعلى الأغلب يقصــد به ذلك النموذج الثاني،

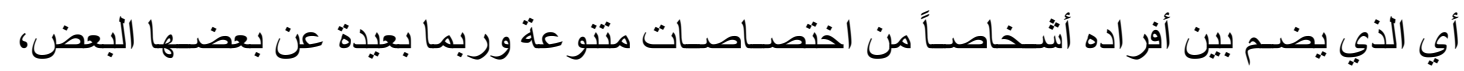
كاجتماع طبيب الأسـرة مع الطبيب النفسـي مع المعالج النفسـي و المرشـــ النفسـي وقد يمتد إطار الفريق ليشمل كذللك اختصـاصي القانون ورجل الدين أيضاً في بعض الحالات، مع إمكانية دخول

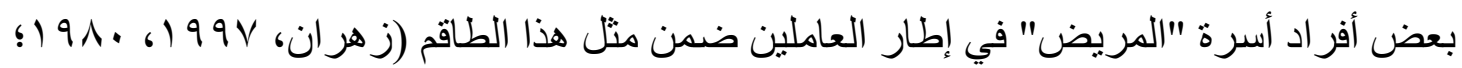

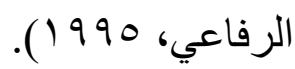
وتتحدد واجبات أعضــــاء الفريق بالارجة الأولى في التفهم و الانفتاح و التقبل لاختصـــاصـــات الآخرين وخبر اتهم ووجهات نظر هم، بهدف تأمين الرعايـة المتكاملـة المتلى للحالات التي تقع ضمن مجالات عملهم. إن اندماج أعضاء الفريق في وحدة متكاملة يؤدي في العادة إلى التقليل من الحسـاسـيات الناجمة عن موضـوع تر اتب السـلطة بين أعضـاء الفريق، وينعكس هذا إيجاباً على مستوى الخدمة المقدمة من قبلهم للأفر اد. ، Challela أما الســـات التي ينبغي أن تتوفر في أعضـاء الفريق الفعال فيمكن أن نأخذها عن 1979 التي تجملها في أربع نقاط: 1. معرفة كل فرد من أفراد الفريق بحدود اختصاصه وبدوره في الفريق. ץ. المعرفة الجيدة بالمسـائل التي تتطلب استقاء المعلومات عنها ومو اجهتها بشـكل مشـترك من اختصاصات مختلفة، أو ما يسمى المجالات البينية. r. المعرفة الجيدة بطبيعة اختصاص بقية أفر اد الفريق وما يستطيع كل منهم تقديمه. ع. ـأن يطور أفر اد الفريق قدر اتهم على التأثير و المشاركة المتبادلة في بر امج الفريق ككل. وتتناول سـتين (Steen, c., 1992) مز ايا العمل ضــن الفريق العلاجي، من وحي التجربة البريطانية الخاصـة بهذا المجال، فيما صـار يسـى اعتيادياً هنالك بفريق الرعاية الأولية Primary Care Team؛ 
فتذكر مجمو عة من المز ايا التي تفيد كلاً من طرفي العملية، أي المتخصص و المتعالج في آن معاً،

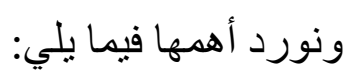
- الإحاطة و الثــول بتفاصـيل دقيقة من خلال تجمع المعلومات على مدى زمني طويل، ومن خلال علاقات الاختصـاصيين المختلفة بالمحيط العام للفرد (طبيب الأسـرة، الطبيب النفسي،

$$
\text { المتخصص الاجتماعي ..الخ). }
$$

- الدقة في التشخيص لبو ادر المرض وتداركه قبل استفحاله من خلال منهج الوقاية الأولية. - - التغيير التـريجي لاتجـاهـات العـاملين ضـــمن الفريق حيـال إمكـانـات بقيـة العـاملين فيه و اختصاصاتهم. - اكتشـاب العادات الجيدة بين الاختصـاصـيين، فيما يتعلق بمهار ات المقابلة وجمع المعلومات وبناء علاقة الثقة مع طالبي المسـاعدة، من خلال العمل على أرض الو اقع وملاحظة مهار ات المتخصصين الآخرين في الفريق.

ويضيف مانزي في نفس هذا المجال مكاسـب مهمة يحققها المرشد النفسي من خلال عمله ضمن فريق من هذا النوع، تتجلى في: - ازدياد الثــعور بالثقة و الدعم لدى المرشــدين من خلال عملهم مع الآخرين و إمكانيات الدعم المتبادل فيما بينهم. - ازدياد المعلومات الميدانية المتعلقة بالإحالات وحالات الاضطر ابات الجسدية. - - تعمق الفهم الكلي للحالات الفردية.

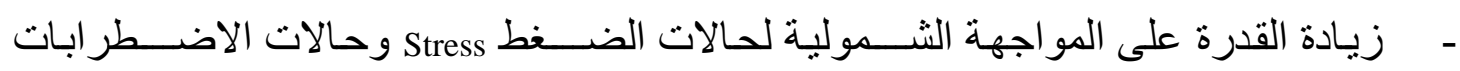
السيكوسوماتية . (Manzi, C., 1992).

لقد أصـبحت مشـاركة المتخصـصـين النفسـيين و الاجتماعيين و غير هم ضـرورة اقتضـتها طبيعة الأمر اض و التحول الحاصــلـ في طريقة فهمها وتناولها من جهة، و التطور الحاصــلـ في الوعي الصـحي و النفسـي والاجتماعي الذي تتعكس آثاره على الوضـع الإنتاجي للفرد و الاقتصـادي على المستويات الجماعية بصورة إيجابية (Grawe, Donati \& Bernauer,1994). يمكن القول إذا أن هذا التطور المشار إليه أعلاه لم يأت من فراغ و إنما سبق ذلك تحول في الوعي و الاتجاهات سو اء من ناحية المجتمع أم من ناحية التخصصات المختلفة وأهمها الطب الذي أخذت مسـألة مر اعاة الجوانب النفسـية و الاجتماعية في الأمر اض المزمنة و الوقاية منها أو منع تفاقمها تفرض نفسها عليه وتدفعه لتعديل اتجاهاته التقليدية. 
ومن نافلة القول الإشـارة إلى أن المؤسسـات الصـحية في الوطن العربي ماز الت بعيدة عن مواكبة هذه التغير ات وماز الت تحت تأثنير الظروف الاقتصـادية الر اهنة و المفاهيم التقليدية السـائدة حول المرض و العلاج و هيمنة المؤسسـات الطبية بادعائها أن قضـايا المرض والصـحة من مسؤوليتها وحدها، على الرغم من أن الوعي الاجتماعي و النفسي والاقتصـادي بالتحديد يحمل مؤشرات تدفع باتجاه إعادة النظر في هذه المفاهيم و السـياسـات الصـحية المتبعة تحت ضـغط الانفجار الكبير في التكاليف و الإر هاقات النفسـية والاجتماعية الناجمة عن الأمر اض المزمنة عموماً والمؤدية إليها أيضاً (راجع عطية، بو 199 ) ). إن نظرة عامة إلى مناهج كليات الطب في الوطن العربي تتيح لنا اســتنتاج أن التأهيل النفسـي للأطباء في التعامل مع الأمر اض المزمنة والمسـتعصسية وفي أسـاليب الوقاية النفسية و المسـاعدة النفسـية في الأزمات هو تأهيل منو اضــع بل شـبـه معدوم وبالتالي فإنه لا يمكن بأي شــــل من الأشــكال اعتبار أن الأطباء وفق مسـتوى التأهيل الر اهن مؤهلون للتعامل مع الجو انب النفسـية و الاجتماعية للأمر اض. وبالتالي لا نســنطيع افتر اض أن الأطباء يمتلكون معارف نفسـية كافية

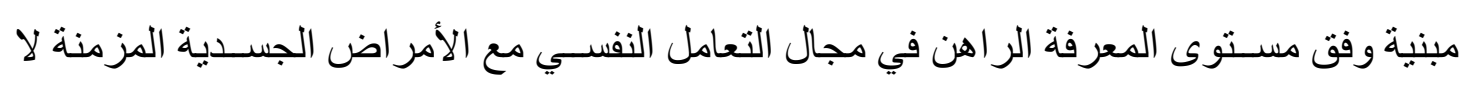
عند تخرجهم و لا بعد أن يتخرجوا، وبالتالي وبناء على ذلك يمكن افتر اض أن مـا هو متوفر من إدر الك لأهمية هذا الموضـوع هو عبارة عن اتجاهات عامة تعكس رؤى شـخصـية قد تكون نابعة

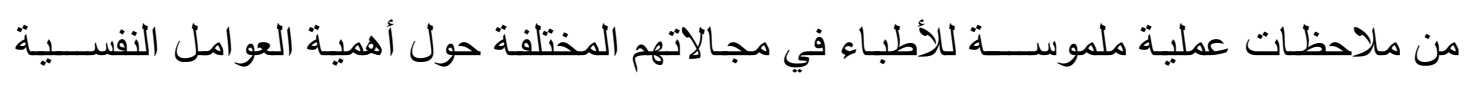
و الاجتمـاعيـة في نشــوء الأمر اض المزمنـة وغير هـا وتأثنير هذه العو امل على العلاج و أهميـة الاستعانة بالمساعدة النفسية التي يقدمها متخصصون في هذا المجال. وقد تكون هذه الرؤى نابعة

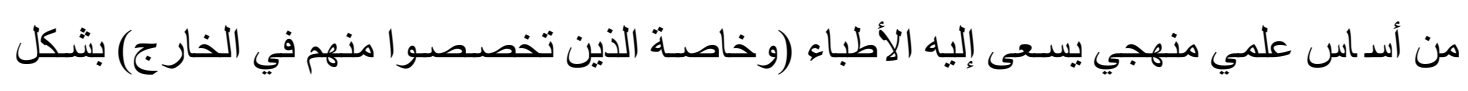
منفرد على أساس من جهذ فردي غير منظم بعد. ولهذه الاعتبار ات ومع النقص الكبير في الدراســات العربية المتعلقة بهذا المجال كان لابد في البداية من الســـي إلى اسـتقصــاء مدى إدر الك و تقبل الأطباء في بيئتنا المحلية ــ كخطوة أولىــ لمسـألة الوجوه النفسـية للأمر اض ومفهومهم حول طبيعة المرض و التشـخيص و العلاج وللتعاون بين الطب و علم النفس، لا في مسـألة الأمر اض والاضطر ابات النفسية فحسب و إنما في مجالات

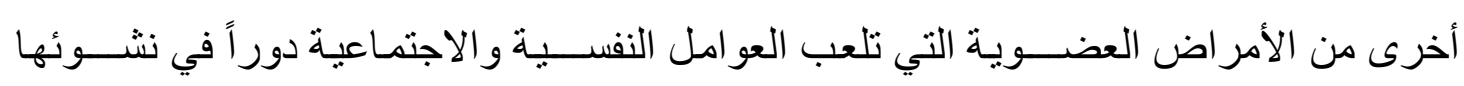
واستمر ارها إلى جانب العو امل الفيزيولوجية. 
وتعثبر در اسـة الاتجاهات السـائدة ـالتي قد تعكس ر أياً علمياً أو شـخصـياً كما أشـرناسـابقاً. هي

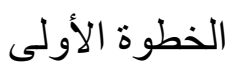
في هذا المجال التي تتيح لنا الاســتفادة من الاتجاهات الإيجابية ،أي المتفقة مع نتائج التوجهات الطبية العالمية الحديثة و الدر اسـات العلمية وتتميتها، و السـعي إلى تعديل الاتجاهات الخاطئة التي قد تعيق التعاون وتنسعى إلى إبقاء الأوضـاع على ما هي عليه بغض النظر عما لذللك من تأثير ات اقتصادية واجتماعية سلبية على الأفر اد و الجماعات. ومن هنا تتمثل مسـألة البحث الر اهن في اسـتقصــاء اتجاهات عينة من الأطباء في مدينة دمشـق حول الأمر اض النفسـية و الجســية وحول العو امل فيها وأسـاليب مو اجهتها وإثـر اك المتخصـص النفسي في التشخيص و العلاج و إعادة التأهيل ....الخ.

\title{
ثاتياً: الدراسة الميدانية وخطواتها
}

\author{
أهداف الدراسة: \\ هدفت الدارسة الحالية إلى:
}

ـ معرفة اتجاهات أطباء عينة الدر اسة نحو العوامل النفسية في نشوء وتطور الأمر اض النفية و الجسدية.

- معرفة اتجاهات أطباء عينة الدر اسة نحو أساليب معالجة الأمر اض النفسية. - معرفة اتجاهات أطباء عينة الدر اســة نحو العوامل التي يمكن أن تســـهم في نشــوء وتطور الأمر اض النفسية و الجسدية.

- معرفة اتجاهات أطباء عينة الدر اسة حبال إثر الك المتخصص النفسي في العلاج و التشخيص لفئات معينة من الأمر اض. - معرفة اتجاهات أطباء عينة الدر اسة نحو العمل المستقل للمتخصص النفسي. - معرفة وجود أو عدم وجود ارتباطـات ذات دلالة فيما بين الاتجاهـات المتعلقة بـالمســائل الفرعية التي تشكل في مجمو عها الاتجاه حيال الخدمات النفسية على وجه العموم. - التعرف إلى الفروق الموجودة بين الأطباء الأقرب للاختصـاص النفسي (الأطباء النفسـبين) وبين سو اهم من الأطباء في اتجاهاتهم العامة والفر عية حيال مسائل الخدمة النفسية. 
اشـتملت عينة البحث على س /1 من الأطباء من تخصـصـات مختلفة وافقوا على التطوع للبحث. وقد توز عت التخصصات وفق النسب التالية الموضحة في الجدول ( ( ) وكما نلاحظ من الجدول ا فقد احتلت نسبة أطباء الداخلية المرتبة الأولى تلاها تخصصـا الأطفال و الجر احة ثم الهضـمية والقلبية وبعد ذلك النسـائية والطب العام، وجاء أطباء العصبية في المرتبة النهائية.

\begin{tabular}{|c|c|c|}
\hline الــــــــــــــة & العدد & الاختصاص \\
\hline المئوية & & \\
\hline$\%$ Yo,, & rq & داخلية \\
\hline r, & 10 & هضمية وقلبية \\
\hline$\% \neg, r$ & V & عصبية \\
\hline$\% 1 \leq, r$ & 17 & أطفال وجر احة \\
\hline$\% 1,7$ & ir & نسائية \\
\hline$\% 11,0$ & r & طب عام \\
\hline$\% \wedge, 7$ & YI & طب نفسي \\
\hline$\% 1 \ldots$ & $11 \pi$ & المجموع \\
\hline
\end{tabular}

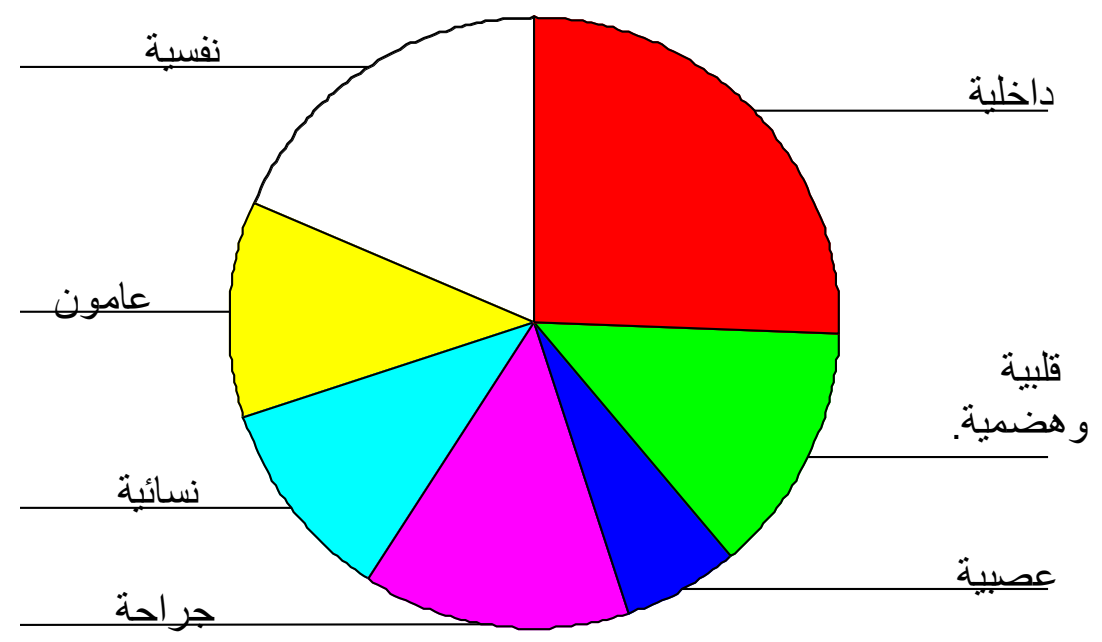

شكل رقم ا : توزع الأطباء حسب اختصاصاتهم في العينة

أداة الدراسة:

اســتخدم الباحثنان اســمارة من إعدادهما مؤلفة من هب بنداً (راجع الملحق رقم 1) تســتقصسي الاتجاهات نحو مجمو عة من المتغير ات مثل العو امل المسـاهمة في نشـوء مجمو عة من الأمر اض مل 
المختلفة وأسـلوب العلاج ومسـألة إثـر اك المتخصـص النفسـي في التشـخيص و العلاج و التعاون ضـــن فريق عمل مشــرك و والحاجة لوجود متخصـص نفسـي في المؤسـســات الصــية العامة و العو امل النفسية في الأمر اض السيكوسـوماتية و عمل المتخصـص النفسي في عيادة خاصــة. تم تصـــميم حقول الإجابة وفقاً لطريقة ليكرت في قياس الاتجاهات، حيث تتدرج الإجابة بين موافق جداً - موافق- لا رأي لي- غير موافق - غير موافق بالمرة. وقد خضعت الاستبانة لحساب الاتساق الداخلي من خلال حساب معامل الارتباط بين الدرجة على كل بند من بنودهـا والدرجة الكلية للعينـة. وقد كانت جميع قيم ألفـا تتراوح بين OV, • و ـ T, . وبلغت درجة الارتباط العام لألفا آج, • و هذا يشــير إلى اتسـاق داخلي جيد، الأمر الذي يتيح لنا اعتبار الاستبانة صالحة لما وضعت من أجله.

\section{التحليل الوصفي للنتائج:}

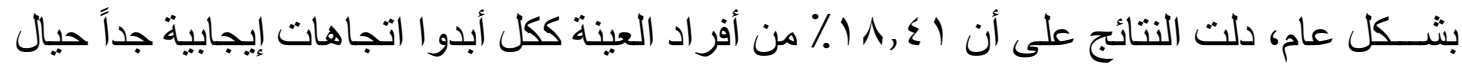

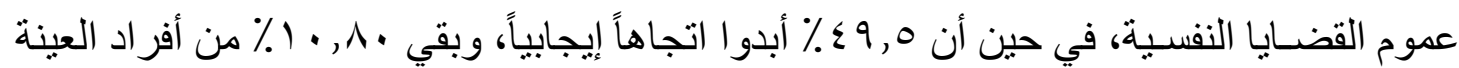

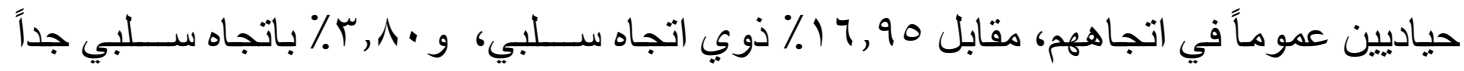
(انظر الثــكل ب). وقد كانت النتائج محملة بتثـتنات معيارية كبيرة نسـبياً، الأمر الذي لا يتيح لنا اســتنتاج مقو لات جازمة بثـــكل عام انطلاقاً من النتائج الكلية، الأمر الذي حتم علينا المر اعاة التفريقية لكل بند على حده. وهذا أمر غير مفاجئ للباحثين، نظر اً لطبيعة الاســتبانة التي انطوت على بنود تقيس الاتجاهات نحو موضو عات عديدة، مرتبطة على كل حال بجو انب متنو عة تشكل بمجموعها جو هر الاتجاه حيال القضايا النفسية. بينت النتائج أن شــدة الاتجاهات حيال كل بند من بنود الاســتمارة على حدة كانت موزعة على النحو المبين في الجدول رقم (Y)، وقد كانت أبرز النتائج في هذا الجدول لفتاً للنظر هي النتائج

البند الثالث: كانت نســبـة من يرون أن الدواء النفسـي هو الطريقة الأفضـــل لمواجهة

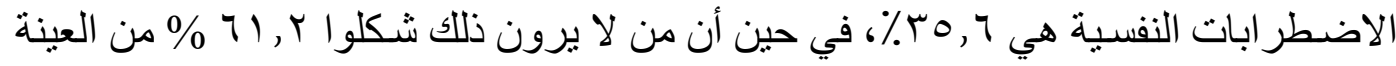

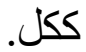

البند الر ابع: يعتقد V V \% من المفحوصين أن من الضـروري إثـر الك المتخصص النفسي في عملية تشخيص الاضطر ابات النفسية، في حين أن ؟, • ب٪ منهم لا يرون ضرورة لذلك. 
البند الخامس: إن VV\% من المفحوصـين يرون ضـرورة إثــر اك المتخصـص النفسـي في مو اجهة اضطر ابات السيكوسوماتية، في حين أن V, V \% منهم لا يرون حاجة لذلك. البند السـابع: إن نسـبة مرتفعة نسـبياً من الأطباء المفحوصـين يعتقدون بأن العلاج بالصـدمة

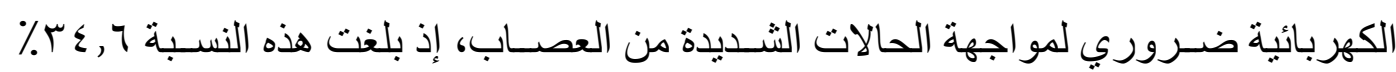

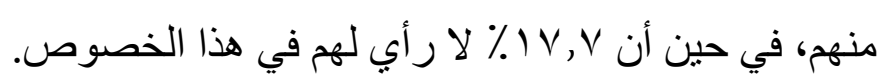
البند التاسـع: يرى عدد كبير من المفحوصسين أن للعو امل النفسية أثراً مهماً في نشـوء وتطور

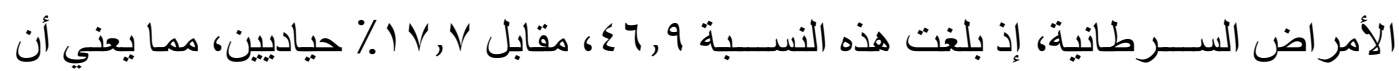
النسبة الأكبر من المفحوصين يقرون بأهمية العو امل النفسية في هذا المجال. البند الحادي عثر: كانت نسبة الذين يرون ضرورة إثر الك المتخصص النفسي في الإشر اف على المرضـى بأمر اض جسـدية مستعصدية هي ، ^٪ تقريباً، مقابل 1 (\% غير مو افقين على مثل هذا الاشــتر الك. وهذا يعني أن الأغلبية العظمى من أطباء عينة البحث يمتلكون اتجاهاً إيجابياً واضحاً نحو اشر الك المتخصص النفسي في الإشر اف على هذه الحالات. الجدول (r)): النسب المئوية لإجابات أفراد العينة ككل على كل بند من بنود الاستبانة

\begin{tabular}{|c|c|c|c|c|c|}
\hline غبير مو افق & غير موافق & حبادي & مو افق & موافق جداً & رقم البند \\
\hline $0, r$ & $77, \varepsilon$ & 1,1 & $r, 1$ & $\varepsilon, \varepsilon$ & 1 \\
\hline 1,1 & r & 1,1 & 71,1 & $r, 1$ & r \\
\hline$\Lambda, 1$ & or, & $r, 0$ & $r \cdot, 1$ & $0, \pi$ & r \\
\hline$\varepsilon, \varepsilon$ & 10,9 & $\wedge$ & $0 \leqslant$ & $I V, V$ & $\varepsilon$ \\
\hline$\varepsilon, \varepsilon$ & $1 \pi, \pi$ & $0, r$ & 71,1 & 10,9 & 0 \\
\hline 1,1 & $q, v$ & $r, V$ & $v \varepsilon, r$ & 11,0 & 7 \\
\hline 10 & $r, V$ & $I V, V$ & $r q, r$ & $0, r$ & v \\
\hline . , 9 & $0, r$ & $r, 0$ & $O r, Y$ & $r_{\Lambda}, 1$ & ᄉ \\
\hline $0, r$ & $r \cdot, 1$ & $I V, V$ & $\leqslant r, 0$ & $\varepsilon, \varepsilon$ & 9 \\
\hline . , 9 & $\wedge$ & $0, r$ & 09,9 & 10,9 & 1. \\
\hline 1,1 & 10 & $r, 0$ & $7 \varepsilon, 7$ & 10 & 11 \\
\hline$\cdot, 9$ & $r, 0$ & $0, r$ & $\varepsilon V, \lambda$ & $\leqslant r, 0$ & ir \\
\hline 1,1 & rT,. & $r r, 1$ & $\varepsilon \vee, \Lambda$ & $0, r$ & r \\
\hline., 1 & $\varepsilon, \varepsilon$ & $0, r$ & $0 ., \varepsilon$ & $r q, \wedge$ & $1 \varepsilon$ \\
\hline - , 9 & $\wedge$ & $r, V$ & $r \wedge, q$ & $\leq 9,7$ & 10 \\
\hline $1 \varepsilon, r$ & $\varepsilon r, 0$ & r, & $T, Y$ & $\cdot, 9$ & 17 \\
\hline 1,1 & $r, T$ & $r, V$ & $0 ., \varepsilon$ & $r_{\Lambda}, q$ & IV \\
\hline - , 9 & $r \wedge, q$ & $0, r$ & $\{0,1$ & $q, v$ & 11 \\
\hline$r, 0$ & r, & $v, 1$ & $\varepsilon \vee, \wedge$ & $0, r$ & 19 \\
\hline$r, V$ & $1 \varepsilon, r$ & $1 \cdot, 7$ & $0 q, r$ & IT, & $r$. \\
\hline $1 \varepsilon, Y$ & $1 \cdot, 7$ & $T V, T$ & $v, 1$ & $\cdot, 9$ & Y \\
\hline · & $7, Y$ & V & $V Y, T$ & $1 \varepsilon, Y$ & YT \\
\hline 1,1 & 17,1 & $r, 0$ & $09, \pi$ & 11,7 & Tr \\
\hline$\cdot, 9$ & 1,1 & $r, 0$ & $\varepsilon 9,7$ & $\varepsilon \varepsilon, Y$ & Y $\varepsilon$ \\
\hline $1 \varepsilon, r$ & 17,1 & $r_{\cdot}, \varepsilon$ & $r q, 1$ & $\wedge, \wedge$ & ro \\
\hline
\end{tabular}


البند الثاني عشر : معظم أطباء عينة البحث يؤيدون العمل ضمن فريق أو طاقم علاجي يشمل الطبيب النفسـي و المتخصـص النفسـي جنباً إلى جنب مع متخصـصـين آخرين، وهي نتيجة متسقة مع الاتجاهات العالمية الحديثة في هذا الميدان كما بيناها في القسم النظري. وجود شـيء من التناقض في نتائج البندين ^ و با ا، حيث تشـير الإجابات على البند ^ إلى أن ץ, 19 ٪ من المفحوصــين يرون أن جذور الاضـــر ابات النفسـية تعود إلى ماضـــي الفرد وخبر اته السـابقة، في حين أن الإجابات على البند رقم سا ا، تشير إلى أن نسبة المو افقين على ألى أن أهم العو امل المســؤولة عن الاضــطر ابات النفسـية هي العو امل الكيماوية الدماغية بلغت

1, 1\%، و هو ما يشير إلى اتجاهين متناقضين عند المفحوصين في هذه الناحية. هنالك نسـبة مرتفعة من الأطباء الذين يعتقدون بالحاجة إلى وجود المتخصــص النفسـي في

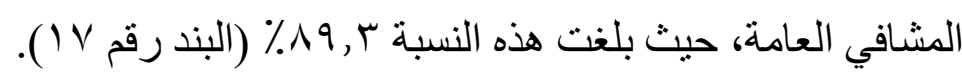
بنتيجة البند ^ ا تبين أن ^, §ه \% من المفحوصين يرون أن الطبيب النفسي هو وحده القادر على تشخيص الاضطر ابات النفسية.

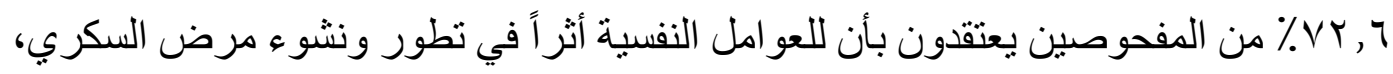
و هي نتيجة تتسق مع كون نسبة كبيرة منهم (^, T^^) يرون أهمية العوامل النفسية في نشوء

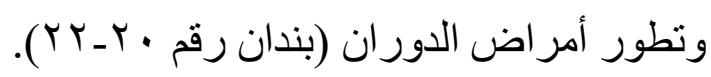

\section{الشكل 2}

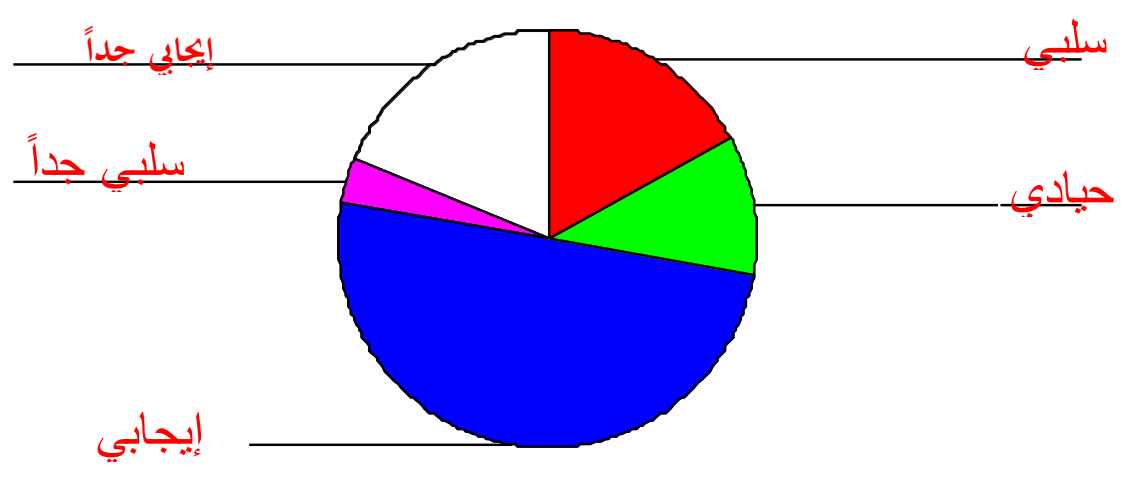

أما عن فائدة عمل المتخصص النفسي في عيادة مستقلة فإن الإجابات كانت على العموم غير

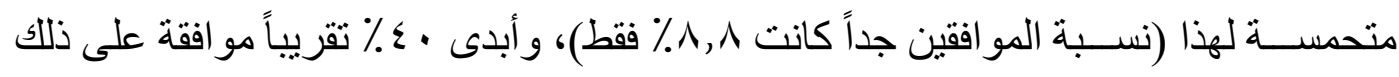

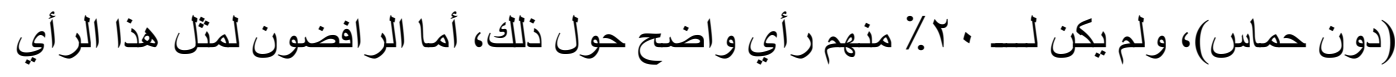
فقد بلغت نسبتهم اس\% 
اتجاهات الأطباء بتخصصاتهم المختلفة نحو مهن المساعدة النفسية يثبر عرض النتائج في الفقرة السـابقة إلى وجود تأرجح كبير في الاتجاهات، الأمر الذي لا يمكن من اســتنتاج مقو لات تفريقية حول البنود كافة. ونتيجة لذلك فقد تمثلت الخطوة الثانية بضــرورة المر اعاة التفريقية لكل اختصاص على حدة فيما يتعلق بالاتجاهات نحو متغير ات الاستبانة لنتمكن نتيجة لذلك من معرفة اتجاهات كل فئة من الفئات بشكل أدق نحو المتغير ات المدروسة. تمثلت الخطوة الأولى في هذا الإطار بتحديد خمس مجمو عات عريضـة من المتغير ات حُددت كما يلي

ا ـ العو امل النفسية التي يمكن أن تسهم في نشوء مجمو عة من الأمر اض الجسدية والنفسية. r. مسألة التعاون بين المتخصص النفسي والأطباء في المجالات المختلفة . r. العمل ضمن فريق يضم المعالج النفسي الاختصاصي. ع. مســألة تفضــيل طريقة معينة لعلاج الأمر اض النفسـية، كالعلاج النفسـي أم الكيميائي أم بالصدمات.

•. مسألة عمل المتخصص النفسي في عيادة مستقلة.

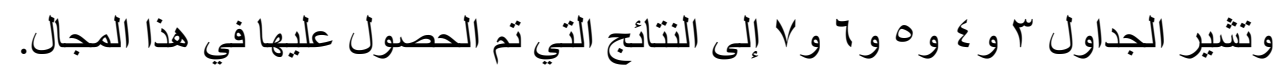
الجدول (r) العوامل النفسية المساهمة في نشوء أمر اض جسمية ونفسية مختلفة الفمية التخص العو امل النفسية المساهمة في نشوء أمر اض جسمية ونفسية مختلفة

\begin{tabular}{|c|c|c|c|c|c|c|}
\hline \multicolumn{2}{|c|}{ إيجابي\%\% } & \multicolumn{2}{|c|}{ حيادي\% } & \multicolumn{2}{|c|}{ سلبي \% \% } & \\
\hline من العينــة & من العينـة & من العينة & من العبنــة & مــــــن & مـــــن & \\
\hline ككل & الفر عية & ككل & الفر عية & العينــة & العينــة & \\
\hline & & & & ككل & الفر عية & \\
\hline$\%$ $\wedge, 0$ & $\% \wedge ৭, \vee$ & $\%, 9$ & $\%$ \% & $\%, \wedge$ & $\% 7,9$ & داخلية (ن=و r) \\
\hline$\% 1 \Gamma, \varepsilon$ & $\% 1 \ldots$ & - & - & - & - & قلبية و هضمية(ن= 0 (1) \\
\hline$\%$ & $\% 1 \ldots$ & - & - & - & - & عصبية ( ن= V \\
\hline $1 \pi, \varepsilon$ & $\% ৭ \uparrow, \vee$ & - & - & $\% \cdot, 9$ & $\%$ & جر احة و أطفال(ن= 17 \\
\hline $1 \cdot, \Lambda$ & $\% 1 \ldots$ & - & - & - & - & نسائية ن= Y r I ) \\
\hline $1 \cdot, \mathrm{V}$ & $\% 99,1$ & $\% \cdot, 9$ & $\% \vee, \vee$ & - & - & عام( ن=س I ) \\
\hline $1 \wedge, 7$ & $\% 1 \ldots$ & - & - & - & - & طب نفسي (ن= \\
\hline
\end{tabular}


يبين الجدول رقم (r) أن اتجاهات الأطباء على اختلاف تخصصـاتهم كانت إيجابية بشكل ملحوظ فيما يتعلق بكون العو امل النفسـية ذات أهمية في نشــوء وتطور الأمر اض النفسـية والجســدية المختلفة. تجلى هذا أحياناً كما في اختصـاص الطب النفسي، الذي كان جميع أفراد عينته يتصفون باتجاه إيجابي نحو هذه المسـالة بلا اسـتنتاء. ويمكن القول أنه حتى في التخصـصـات الأخرى فإن نسبة الأطباء الذين كانت لهم اتجاهات سلبية حيال هذا الأمر كانت نسبة هامشية تقريباً لم تتجاوز

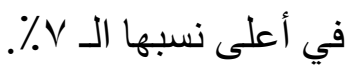
يبدو من نتائج الجدول رقم (ع) فيما يخص اتجاهات الأطباء حيال التعاون مع المتخصص النفسي تشخيصـاً و علاجاً ور عاية لأنو اع مختلفة من الأمر اض النفسية والجسمية ذات الطابع النفسي، أو تللك التي تحتاج إلى رعاية نفسية خاصة، فقد بدا لنا و اضحاً أن هناك اتجاهاً عاماً إيجابياً نحو هذه القضـــــة. فالأطباء يعتقدون إذاً بضـــرورة مثل هذا التعاون، على الرغم من وجود تفاوت بين الاختصـاصـات المختلفة في درجة هذا التحبيذ، تبلغ ذروتها لدى أطباء الداخلية، الذين بلغت نسبة السلبيين منهم حيال الموضوع 9 , • بـ٪.

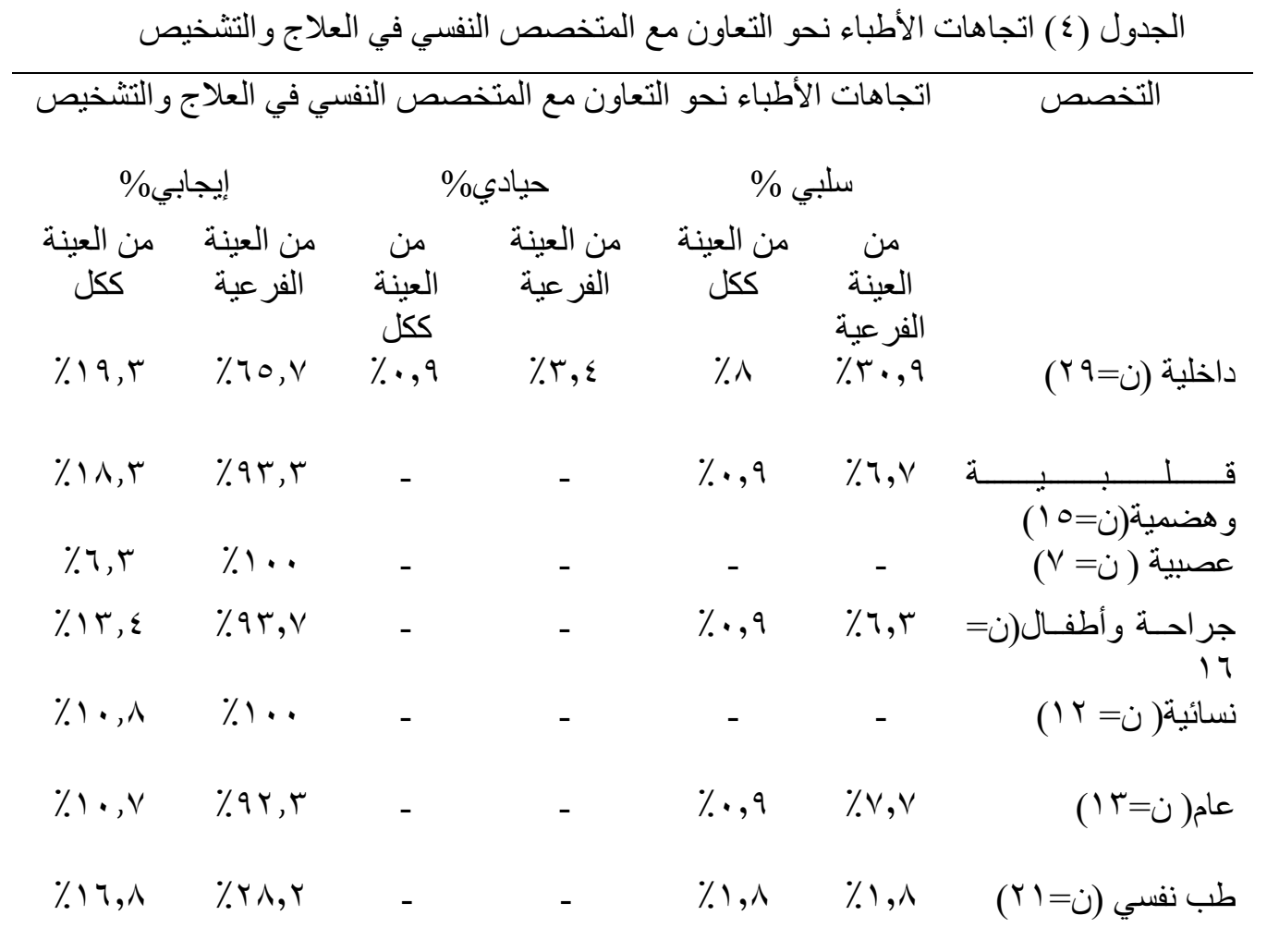




\begin{tabular}{|c|c|c|c|c|c|c|}
\hline \multicolumn{6}{|c|}{ اتجاهات الأطباء نحو العمل ضمن فريق علاجي يضم المتخصص النفسي } & التخصص \\
\hline \multicolumn{2}{|c|}{ إيجابي\%\% } & \multicolumn{2}{|c|}{ حيادي\% } & \multicolumn{2}{|c|}{ سلبي \% } & \\
\hline كـل العيــــة & من الفرعبة العينــة & كـل العينـة & من العينة & كـل العينـة & من الفر عبة العينــة & \\
\hline$\% r r$ & $\% \wedge q, \vee$ & $\% 1, \wedge$ & $\% 7,9$ & $\%, 9$ & $\%$ ऍ, & داخلية (ن=9 (ץ) \\
\hline$\% \backslash, \varepsilon$ & \% & $\%, 9$ & $\% \neg, \vee$ & - & - & 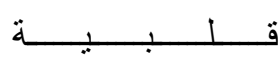 \\
\hline$\% \varepsilon, 0$ & $\% \vee 1,0$ & - & - & $\% 1, \wedge$ & $\% \curlyvee \wedge, \uparrow$ & 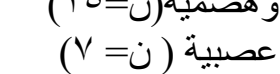 \\
\hline \% & $\% ৭ \uparrow, \wedge$ & $\% \cdot 9$ & $\%$ & - & - & جر احـة و أطفـال(ن= \\
\hline$\% 9, \wedge$ & $\% 91, \vee$ & - & - & $\% \cdot 9$ & $\%$ \% r & 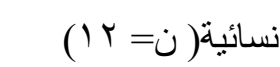 \\
\hline$\%, \vee \vee$ & $\% \wedge \varepsilon, \vee$ & $\%, 9$ & $\%, \vee$ & $\% \cdot, 9$ & $\% \vee, \vee$ & عام( ن=س I ) \\
\hline$\%, \mathrm{~V}$ & $\%$ & $\% \cdot, 9$ & $\% \varepsilon, \wedge$ & - & - & طب نفسي (ن= \\
\hline
\end{tabular}

إن استعر اض النتائج المبينة في الجدول رقم (0) ترينا، أن الميل إيجابي عموماً نحو مسألة العمل مع المتخصـص النفسـي ضــن فريق علاجي متكامل، وبلغت هذه المو افقة ذروتها لدى الأطباء النفسين بمقدار r ب0 9، في حين أن أقل نسبة للمو افقة ظهرت لدى الأطباء العصبيين، الذين كان

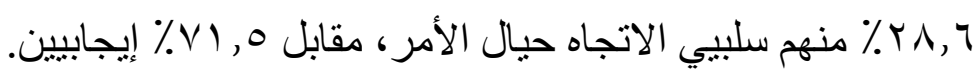
جدول (7) اتجاهات الأطباء نحو العلاج النفسي للأمر اض النفسية

\begin{tabular}{|c|c|c|c|c|c|c|}
\hline \multicolumn{6}{|c|}{ اتجاهات الأطباء نحو العلاج النفسي للأمر اض النفسية } & \multirow[t]{2}{*}{ التخصص } \\
\hline \multicolumn{2}{|c|}{ 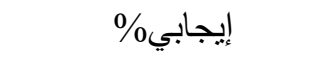 } & \multicolumn{2}{|c|}{ 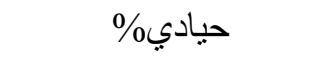 } & \multicolumn{2}{|c|}{ سلبي \% } & \\
\hline 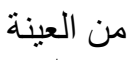 & من العينة & من العينة & 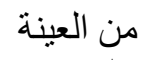 & 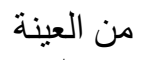 & 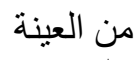 & \\
\hline 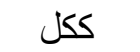 & الفر عية & 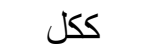 & الفر عية & 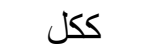 & الفر عبة & \\
\hline$\%, r, \varepsilon$ & $\% \vee q, \varepsilon$ & $\% \Gamma, 0$ & $\%$ & $\% 1, \wedge$ & $\%\urcorner, \wedge$ & داخلية (ن=9q) \\
\hline$\% 11,0$ & $\% \wedge \uparrow, 7$ & $\% \cdot, 9$ & $\%\urcorner, \vee$ & $\% \cdot, 9$ & $\%, \mathrm{~V}$ & ق \\
\hline$\%$ & $\% \wedge 0, \vee$ & $\% \cdot 9$ & $\% 1 \leq, r$ & - & - & عصبية ( ن= V V) \\
\hline$\% 1,7$ & $\% \vee \varepsilon, \wedge$ & $\% \cdot, 9$ & $\%$ & $\% r, v$ & $\% 1 \wedge, 9$ & جر احسة و أطفال(ن= \\
\hline$\% \vee, q$ & $\%$ ○o & $\% 1,1$ & $\% 17, \vee$ & $\% \cdot, 9$ & $\%$ \% r & نسائية( ن= Y I ) \\
\hline$\% \wedge, \wedge$ & $\% \vee 7,9$ & $\% \cdot, 9$ & $\% \vee, \vee$ & $\% 1,1$ & $\% 10, \varepsilon$ & عام( ن=س I) \\
\hline$\% \vee v$ & $\% 90, r$ & - & - & $\%, 9$ & $\% \varepsilon, \wedge$ & طب نفسي (ن= \\
\hline
\end{tabular}


تدل النتائج المبينة في الجدول رقم (؟) على أن اتجاه الأطباء إيجابي على العموم حيال اســتخدام العلاج النفسي في مو اجهة الاضطر ابات النفسية، ولكن هذا الميل يبدو منخفضـاً بعض الثـيء إذا قارناه بما ظهر لديهم من اتجاهات إيجابية حيال المسـئل السـابقة. كان أكثر التخصسصـات إيجابية حيال ذلك هو تخصـص الطب النفسـي (؟0,90\%) في حين أن أقل متخصـصـي جر احة الأطفال

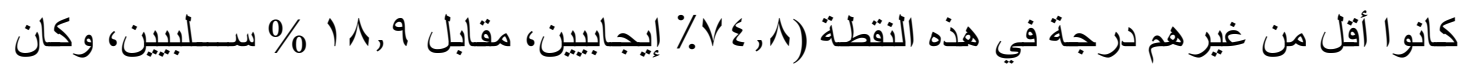

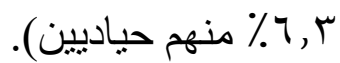

وقد لجأنـا لمزيد من التوضــيح في مـا يتعلق بهذه المســألة إلى مقارنـة نتائج البندين ب و . منفردين، وذلك بسـبب كون بقية البنود المعبرة عن هذه المسـألة بنوداً قد تســهم في تغيير شـكل الاتجاه، لاحتو ائها على أثـكال من المعالجة التي صـار اللجوء إلبها نادراً جداً كالعلاج بالصـدمة الدو ائية، و العلاج بالصــدمة الكهربائية. أما البندان ب و ـ ـ فإنهما يتعلقان فقط بالعلاج النفسـي و العلاج الدو ائي لمو اجهة الاضـطر ابات العصـابية. و أتت النتائج على النحو التالي (راجع الثـكل

ويبدو من خلال الثــكل أن عينـة البحث بـالكامل تميل أكثر إلى العلاج النفســي في مو اجهة الاضــر ابات العصـابية (بند رقم • () من ميلها إلى اســخدام الأدوية في مواجهته (بند رقم س)، ويبدو التفاوت بين هذين الميلين أعظمياً لدى الأطباء النفسيبين، الذين كان اتجاههم حيال اسـتخدام

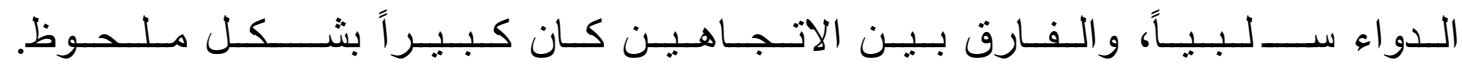
الجدول (V) اتجاهات الأطباء نحو العمل المستقل للمعالج النفسي في عيادة خاصة

\begin{tabular}{|c|c|c|c|c|c|c|}
\hline \multicolumn{6}{|c|}{ اتجاهات الأطباء نحو العمل المستقل للمعالج النفسي في عيادة خاصة } & التخصص \\
\hline \multicolumn{2}{|c|}{ إيجابي\%\% } & \multicolumn{2}{|c|}{ حيادي\% } & \multicolumn{2}{|c|}{ سلبي 0 0 } & \\
\hline من العبنة & مـن العينــة & من العينـة & من العينــة & من العبنــة & من العينــة & \\
\hline ككل & الفر عية & ككل & الفر عية & ككل & الفر عية & \\
\hline$\% \wedge, 9$ & $\% \varepsilon, 0$ & $\%$ & $\%, r, V$ & $\% 11,0$ & $\% \leq \varepsilon, \wedge$ & داخلية (ن= Y (Y) \\
\hline$\%, r$ & $\% \varepsilon$. & $\% \varepsilon, \varepsilon$ & 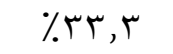 & $\%, \uparrow$ & $\%$ \%,$V$ & 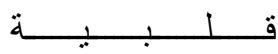 \\
\hline$\%, r$ & $\% \wedge 0, \vee$ & $\%, 9$ & $\% \leq, r$ & - & - & عصبية ( ن = V ) \\
\hline$\% \wedge$ & \% & $\%, 9$ & \% & $\%$ & $\% r v, 0$ & جر احـة و أطفـال(ن= \\
\hline$\% \wedge$ & $\% \vee 0$ & $\% 1, \wedge$ & $\% 17, V$ & $\%, 9$ & $\%$ & نسائية( ن= r I ) \\
\hline$\% \vee, 1$ & $\% 71,7$ & $\% r, V$ & \%r, & $\% 1, \wedge$ & $\% 10, \varepsilon$ & عام( ن=س I) \\
\hline$\%\urcorner, r$ & r, سז\% & $\% \varepsilon, \varepsilon$ & ג, & $\% \vee q$ & $\% \leqslant r, \wedge$ & طب نفسي (ن)= \\
\hline
\end{tabular}


إن نظرة إلى الجدول رقم V تبين يوضـــح أن هنالك تباينات كبيرة في اتجاهات الأطباء من أفر اد عينة البحث حيال قضية عمل المعالج النفسي بشكل مستقل في عيادة خاصة، وبدا هذا التباين أشد

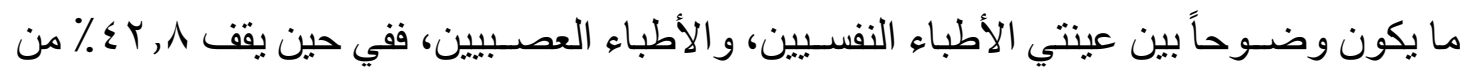

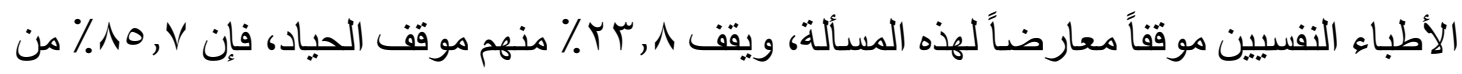
الأطباء العصــبيين يؤيدون هذه الفكرة، و لا يقف منها موقف الحياد ســوى ؟, ـ ( ٪، في حين لم يعارضـها منهم أحد. وكان أكثر الاتجاهات معارضـة لفكرة العيادة الخاصــة للمعالج النفسي بارزاً

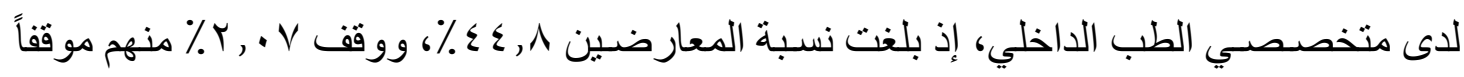
حيادياً. ومما يلفت النظر في هذا الجدول أن عدد نســبة الحياديين فيه كانت مرتفعة بوضــوح

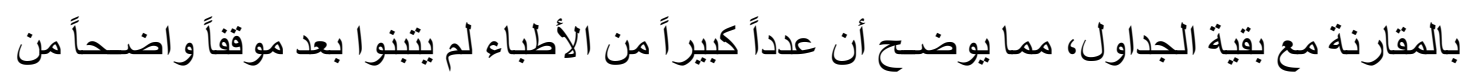
هذه المسألة.

\section{نتائج تحليل الارتباط بين الاتجاهات}

أظهر تحليل الارتباط بين المجمو عات الخمس من متغيرات الاتجاهات الارتباطات الدالة التالية

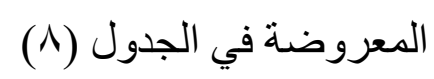

الجدول (^): تحليل الارتباط بين مجمو عات الاتجاهات

\begin{tabular}{|c|c|c|c|c|c|}
\hline نحو العلاج & نحي عيادة العمل & ضمن فريق العمل & نحو العوامل & لتعاون & \\
\hline - & **, שrTr & **, זчт & $* *_{,}, r q \mu$ & - & الاتجاه نحو التعاون \\
\hline$*_{.}, 191$ & - & **, Yา & - & $* *$, , rq & الالتجسيـاه نحو العوامـل \\
\hline$* *,, Y \wedge q$ & سلبي غير & - & $* *,, Y \nearrow \varepsilon$ & **, , & ضمن فريق الاتجــــــو العمـل \\
\hline- & - & - & - & *., & عيادة خاصـة الاتحة العمل في \\
\hline- & - & $* *,, r \wedge q$ & $* ., 191$ & - & الاتجاه نحو العلاج \\
\hline
\end{tabular}

من هذا الجدول يمكن الاسـتنتاج أنه كلما كان الاتجاه إيجابياً نحو التعاون مع المتخصـص النفسي ازداد تقبل الأطباء للعمل معهه ضــمن فريق وازداد تقبلهم لعمله في عيادة خاصــة به. كما ويرتبط الاتجاه نحو إســـهام العوامل النفسـية في الأمر اض المختلفة مع الاتجاه نحو التعاون ومع الاتجاه

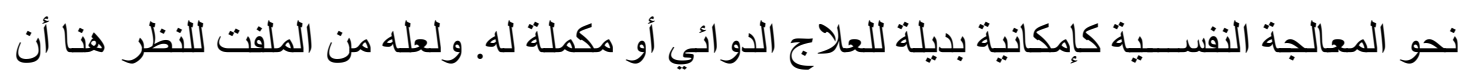


الاتجاه نحو عمل المعالج النفسـي في عيادة خاصـة به لا يرتبط بصـورة دالة إلا مع الاتجاه نحو الرغبة في التعاون فقط في حين أنه ارتبط بصــورة سـلبية ولكن غير دالة مع الاتجاه نحو العمل ضمن فريق - وهذا أمر منطقي - ومع العلاج النفسي للأمر اض النفسية.

تتائج مقارنة متوســات اتجاهات عينة الأطباء النفسـين مع المجموعات الأخرى

من الأطباء

أســفرت نتـائج تحليـل دلالـة الفروق بين المتوســــات لعينـة الأطبـاء النفســيبن و التخصــصــات الأخرى عن مجموعة من الفروق الدالة في الاتجاهات نحو العوامل النفسـية المســاهمة أو المؤثرة في نشــوء طائفة من الأمر اض الجسـدية بين الأطباء النفسيبين وكافة التخصسصـات الأخرى. وقد كان هذا الفرق لصـالح الأطباء النفسيبين. و هذه النتيجة ليست مفاجئة إذ أنه بحكم تخصص الأطباء النفسيين في هذا المجال لابد و أن يكونوا على درابية أكثر من غير هم بـأهمية ودور العوامل النفســية في نثـــوء مجمو عة كبيرة من صور الأمر اض الجسدية والنفسية الجسدية. أما في مســألة التعاون مع المتخصــص النفسـي و إثــر اكه في التشــخــ و العلاج و الإشر اف على مرضى بأمر اض جسدية مزمنة أو في العمل ضمن فريق متخصص يضــم الطبيب و المعالج النفسـي و غير هم فلم تكن هنالك فروق ذات دلالة بين اتجاهات الأطباء. وجدنا فروقاً دالة بين الاتجاهات نحو كون العلاج النفسـي هو الأســلـوب الأمثل لمو اجهة الاضـطر ابات النفسية، كانت هذه الفروق دالة بين الأطباء النفسبين و الجر احين و أطباء الأطفال و النسـائية و الأطباء العامين، وكانت هذه الفروق لصـالح الأطباء النفسيين كذلك. أما فيما يتعلق بالاتجاه نحو العمل المستقل للمتخصص النفسي فقد بينت النتائج أن هناك فرقاً ذا دلالة بين اتجاهات الأطباء النفســبين بالمقارنة مع اتجاهات الأطباء العصبيين و النسـائين، و العامين، ولكن كان الفرق هذه المرة لصـالح الفئات الأخرى، مما يعني أن الأطباء النفسـبين هم أقل ميلاً إلى الموافقة على عمل (9) المتخصص النفسي. الجدول 
الجدول (9): تحليل دلالة الفروق بين المتوسطات لعينة الأطباء النفسيين و التخصصات الأخرى

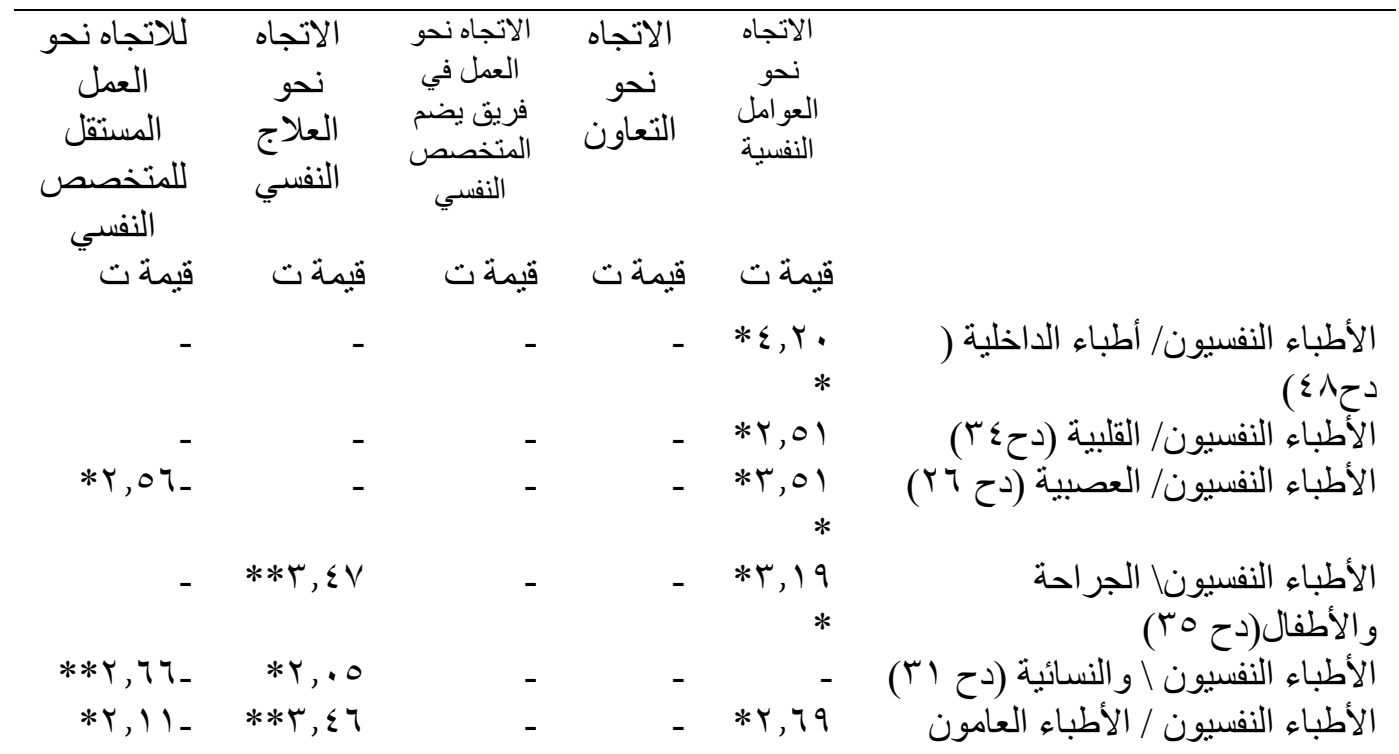

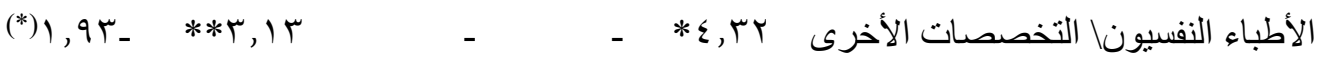

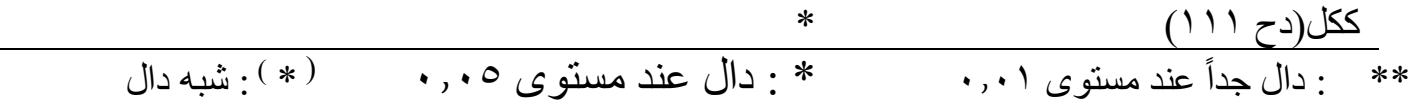

بشكل مستقل في عيادة خاصـة. ويقدم الجدول رقم (^) عرضـاً للفروق الدالة في هذا

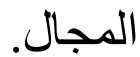

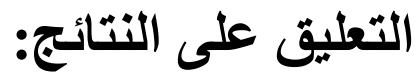

لقد تمثل هدف هذه الدر اسـة في التعرف إلى اتجاهات الأطباء باختصـاصـاتهم المتنو عة من قضـايا تتعلق بمســألة الخدمة النفســية، وقد أتت النتائج لتبين في مجملها أن هذه الاتجاهات هي إيجابية على وجه العموم لدى الأطباء موضـوع الدر اسـة في مدينة دمشـق. وهذه نتيجة تجعلنا نسـتنتج أن هنالك ما يثــعع على اسـتثمار هذه الاتجاهات الإيجابية لتوطيد أشـكال التعاون بين هؤلاء الأطباء وبين المتخصـص النفسـي بما يعود بالنفع على المرضـى بشـكل أسـاسـي، وكذللك على الأطر اف هـ المتعاونة، من حيث زيادة فاعليتها في مو اجهة الاضطر ابات و الأمر اض المتعلقة بالحياة النفسية، سو اء أكانت هذه الأمر اض جسدية أم نفسية محضة. ومن جهة أخرى فإن البحث يظهر أيضــــاً بعض نو احي الاختلاف في وجهات النظر بين الأطباء موضــع الدر اســة، كما يدل في بعض الحالات على وجود اتجاهات متناقضــة منتشـرة فيما بينهم، ونذكر على سبيل المثال الموقف المتناقض من مسـألة عمل المعالج النفس في عيادة خاصـة به، واختلاف وجهات نظر الأطباء العصبيين و النفسيين. وملفت للنظر أيضـاً أن هنالك تقارباً أو تعادلاً بين وجهات نظر الأطباء فيما يخص الطريقة الأمثل لمواجهة الاضـطر ابات العصـابية، بين مؤيد 
لاسـتخدام الدواء كطريقة متلى، وبين مؤيد لاستخدام العلاج النفسي في هذه الحالات، الأمر الذي

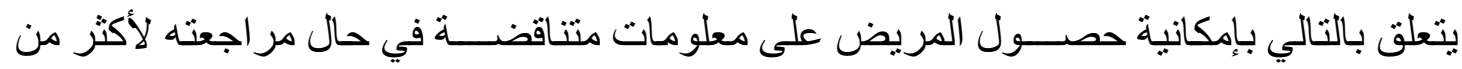
طبيب فيما يخص الجهة أو الطريقة التي ينبغي عليه اتباعها لمو اجهة ما يشــتـكي منه. وفي مثل هذه الحالات نعتقد بضـرورة بذل الجهود باتجاه مزيد من الوضـوح في ما يخص هذه المســلة بين جمهور الأطباء، لكونهم في حالات كثيرة هم الجهة الأولى التي يلجأ إليها المريض بثــكو اه طالباً الحل و الدو اء. وينسـجم هذا مع بعض ما تذكره مر اجع متخصـصـة، عن أن الفترة الزمنية التي قد يقضيها صاحب المشكلة العصابية من حين مر اجعته للطبيب ـ أي طبيب - بخصوص شكو اه، إلى حين وصـوله أخيراً إلى المعالج النفسـي المتخصـص بعلاج مثل حالته قد يسـتغرق وسـطياً عدة

سنو ات (سبع سنوات في ألمانيا) (Grawa , Donati \& Bernauer, 1994). إن التناقض الأســاســي الذي تتحدث عنه المر اجع في مجال العلاقات بين الأطباء عموماً، وبين المتخصـصـين النفسيين، لا يجد في بحثنا هذا سـنداً قوياً من الدعم العلمي، فعلى العموم وجدنا أن الأطباء يظهرون اتجاهات إيجابية بوضـوح حيال مجمل قضـايا الخدمة النفسية، وإن بقيت بعض المسـائل الفرعية محملة باتجاهات سـلبية فإنها لا تشـكل نسـبة كبيرة بين المو اضـيع التي تناولها البحث. إن التاريخ لا يشـترط أن يكرر نفسـه دائماً، و إن المتخصـصـين هم أحرى من غير هم بأن يسـتفيدوا من دروس الآخرين، ليجتنبو ا مز الق وقعوا فيها، و الأمل كبير بأن يتحقق لنا شــيء من هذا في واقع التطبيق العملي، لا فقط على مستوى إعطاء الآر اء المكتوبة، ولعل المحك الأسـاسي لمصداقية مثل هذه التنبؤات سـتظهر عندما يحين الوقت للبدء في إثـر الك الاختصـاصـات النفسية المتنو عة في العناية بالمسـائل الصـحية على أرض الواقع، في مر اكز ومؤسـسـات ومسـتشـفيات الصحة العامة. ولعل مسؤولية المتخصصين النفسيين في هذا المجال ثتمثل في زيادة التو اصل مع غير هم من المتخصصين، أملاً في زيادة الوضوح و الفهم المتبادل لطبيعة وحدود عمل كل منهم. إن كلا الباحثين ينظر ان إلى نتائج هذا البحث على أنها نتائج أولية ذات طبيعة اســـطلاعية، تدعو

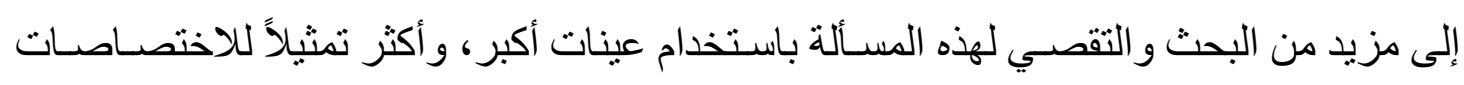
المختلفة، ولســنوات الخبرة المتعددة، وفي أكثر من بلد عربي لتتم المقارنـة وتكتمل الصـــورة الو اقعية بالتالي أمامنا بالتدريج. 

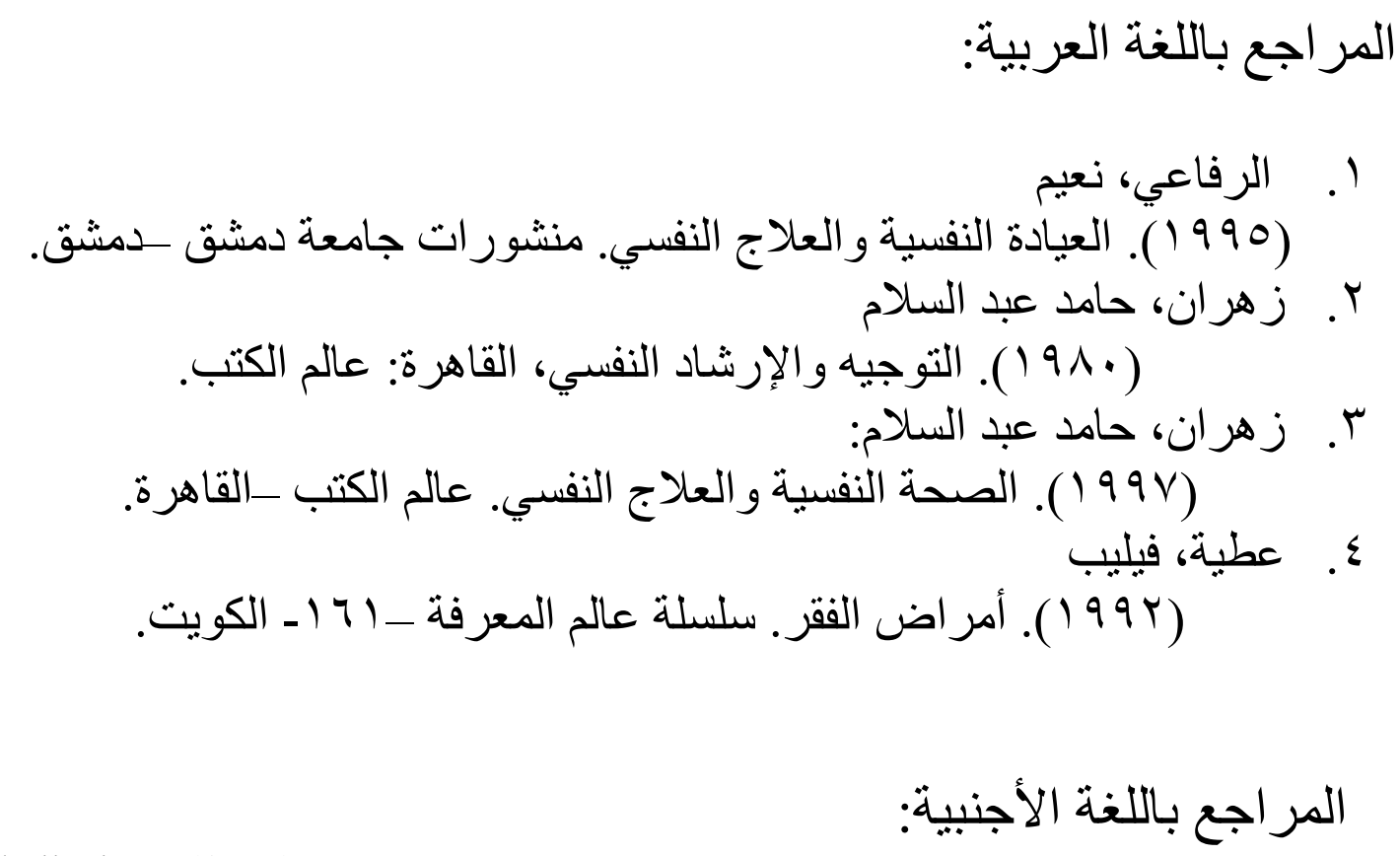

1. Challeal, M. (1979).

The Roll Interdisciplinary Team: Roll definition for Nursing. Image. 11(1).9-15

2. Grawe, K.; Donati R. \& Bernauer F. (1994).

Psychotherapie im Wandel von der Konfession zur Profession.

Hogrefe. Göttingen.

3. Hurrelmann, K. \& Laaser, U. (1993).

Theoretische Grundlagen der Gesundheitswissenschften. In Hurrelmann, K. \& Laaser, U. (3-25) Gesundheitswissenschaften. Handbuch für Lehre Forschung und Praxis. Beltz. Weinheim.

4. Manzi,C. (1992). Option of action. Person Centered Counseling. In Jenkins, R. Newton \& J. Jung, R. (edit). The Prevention of Depression and Anxiety. The Roll of the Primary Car Team. (P.87-)HMSO-London.

5. Schultz, P. \& Hellhammer, D. (1994).

Psychologischer Aspekte chronischer Krankheiten. In Reinecker H. (Hrsg.). Lehrbuch der Klinischen Psychologie.(565-589). Hogrefe. Göttingen.

6. Steen,C. (1992). Mental Health Promotion in General Praxis. In Jenkins, R. Newton \& J. Jung, R. (edit). The Prevention of Depression and Anxiety. The Roll of the Primary Car Team.(P. 155-) HMSOLondon. 